\title{
GARANTIA CONSTITUCIONAL DE PRESUNÇÃO DE INOCÊNCIA E A CONDENAÇÃO PENAL EM SEGUNDO GRAU
}

\section{CONSTITUTIONAL GUARANTEE OF PRESUMPTION OF INNOCENCE AND THE CRIMINAL CONSEQUENCY IN SECOND DEGREE}

Marcelo Negri Soares

Professor e Pesquisador do Programa de Mestrado em Direito UniCesumar - Centro Universitário Cesumar, na linha de pesquisa Efetividade da Justiça e Direitos da Personalidade, lecionando a disciplina Acesso à justiça e Meios adequados de solução de conflitos. Pós-Doutorado pela Uninove/SP (2017). Doutor pela Pontifícia Universidade Católica de São Paulo (2013). Mestre pela PUC-SP (2005). Graduado pela Universidade Estadual de Maringá/PR (1997). Especialista em Direito Processual pela Universidade Paulista (1998), em Direito Comercial pelo Mackenzie (2006), em Direito Público pela Escola Federal de Direito (2008).

E-mail: negri@negrisoares.com.br

Izabella Freschi Rorato

Possui graduação em Direito - UNICESUMAR - CENTRO DE ENSINO SUPERIOR DE MARINGA (2016). Cursa especialização em Direito do Estado com ênfase em Direito Tributário - Universidade Estadual de Londrina (UEL). E-mail: izabella@negrisoares.com.br

Recebido em: 13/06/2018 Aprovado em: 28/03/2018

RESUMO: Considerando a orientação do Supremo Tribunal Federal para acolher, quando preenchidos os requisitos,o início do cumprimento de pena, em regime fechado ou semiaberto,a partir da condenação em segunda instância (STJ - HC 126292, j. 17/02/2016), cabe indagar: decisão como essa pode ferir o princípio constitucional de presunção de inocência? Em outras palavras, é orientação que pode genericamente ser aplicada a todos os casos? Em torno dessa questão, objetiva-se analisar, com apoio nas fontes do direito, a base normativa que estatuiu a presunção de inocência como direito fundamental do homem, trilhandolevantamento histórico e aspectos conceituais, sem se descuidar da importância da aplicabilidade dessa garantia constitucional para a sociedade, a começar pela defesa da garantia legal da liberdade pessoal. Enfim, demonstrando o árduo caminho das garantias internacionais até se alcançar a efetivação do princípio in dubio pro reo, também no plano nacional. Diante desse quadro, com utilização do método hipotético-dedutivo, conclui-se pelo exagero dessa orientação em algumas situações, razão pela qual há que ser analisada sua aplicação em cada caso. O presente artigo finaliza encaminhando alguns balizadores importantes para essa análise. 
Palavras-Chave: Direito Penal e Processual. Presunção de inocência egarantia constitucional. Regime fechado ou semiaberto. Condenação em segundo grau de jurisdição.Início do cumprimento de pena.

ABSTRACT: Considering the orientation of the Brazilian Federal Supreme Court to accept, when the requirements are met, the beginning of the execution of sentence, in a closed or semi open regime, from the conviction in the second instance (STJ - HC 126292, 17/02/2016), a decision such as this may violate the constitutional principle of presumption of innocence? In other words, is it guidance that can generally be applied to all cases? The purpose of this article is to analyze, with support in the sources of law, the normative basis that established the presumption of innocence as a fundamental human right, tracing a historical survey and conceptual aspects, without neglecting the importance of the applicability of this constitutional guarantee to society, starting with defending the legal guarantee of personal liberty. Finally, demonstrating the difficult path of international guarantees until the realization of the principle in dubio pro reo, at the national level. In view of this situation, using the hypothetico-deductive method, it is concluded by the exaggeration of this orientation in some situations, which is why it is necessary to analyze its application in each case. This article concludes by pointing out some important pointers for this analysis.

Keywords:Criminal and Procedural Law. Presumption of innocence and constitutional guarantee. Closed or semi-open regime. Second degree conviction of jurisdiction. Beginningofthesentence.

SUMÁRIO: Introdução; 1. Histórico do princípio in dubio pro reo e presunção de inocência; 2. $\mathrm{O}$ desenvolvimento dos direitos fundamentais brasileiros e a sua relação com o princípio da presunção de inocência; 3. A aplicabilidade do princípio no direito processual penal; 4 .O segundo grau de jurisdição e a aplicação do princípio; 5. Estabelecimento de diferenciação de casos: critério recorribilidade-abrandamento; Conclusão; Referências Bibliográficas.

\section{INTRODUÇÃO}

As garantias à liberdade pessoal é algo mais recente na história. Até o século XVIII, o Direito Penal brasileiro, por se submeter às regras de uma colônia, era informado pela legislação de Portugal e se resumia a penas cruéis e desumanas (tortura e penas físicas eram consideradas legítimas). O direito brasileiro desconhecia, até então, a pena de privação de liberdade, como forma de punição, apenas era utilizada como custódia para garantir a persecução penal, inibindo a possibilidade de fuga.

Ocorre que os legisladores brasileiros dessa época perceberam a necessidade de uma garantia legal da liberdade pessoal, com base em estudos do direito europeu constitucional.

Foi somente com o Código Penal do Império (1830) que a pena privativa de liberdade passou a fazer parte, ao lado das penas cruéis e desumanas, do rol de possibilidades na forma de punição do Direito Penal brasileiro. Mas o banimento das penas cruéis e desumanas foi gradual.

Conforme os anos se passaram, o déficit do direito material estava cada vez mais evidente, portanto, tornando-se necessário aprimorar os estudos na área do direito processual europeu, aprimorando-se o chamado habeas corpus como o remédio processual mais eficiente para solução eficaz dos problemas daquela época. 
Nos dias atuais essa solução possui como alvo principal a prática da equidade, ou seja, a liberdade pessoal deve estar sempre baseada nos princípios da igualdade e não somente na justiça. Para isso, é importante pensar na sociedade como um todo e não apenas no individual.

Nesse passo, ao analisar o capítulo Dos Direitos e Garantias Fundamentais da Constituição Federal brasileira, em especial o art. $5^{\circ}$, inciso LVII, é possível observar o princípio da presunção da inocência, pois estabelece que "todos são iguais perante a lei", incluindo a garantia de que "ninguém será considerado culpado até o trânsito em julgado de sentença penal condenatória". Esse dispositivo foi inspirado na Constituição Portuguesa de 1976, artigo 32 , número 2, o qual estabelece que: "Todo o arguido se presume inocente até ao trânsito em julgado da sentença de condenação". Assim, o acusado tem o direito de requerer e ser informado das provas da sua culpabilidade, ou seja, deverá ser considerado inocente até prova em contrário.

Ora, se por um lado o respaldado no Estado Democrático de Direito, como forma de atendimento dos anseios da sociedade, a qual nomeou seus constituintes com a finalidade e interesse na sua predisposição democrática, exigindo o emprego do Direito Processual Penal e Direito Penal, incorporado nas fronteiras dos princípios da dignidade da pessoa humana, igualdade, legalidade e liberdade; tende a garantir a legitimação do poder por fazer valer a voz do povo; por outro lado, não se nega que a democracia nunca foi o governo de todos- conf. (SCHUMPETER, 1984, p. 32). Todavia, a lei não pode ser transgredida no caso concreto, causando ilegalidades e gerando injustiças.

Afinal, o homem deve manter seu caráter natural de inocência até a comprovação de sua culpa, por meio de analises de provas concretas. Caso não exista circunstancia concreta que prove ato delituoso, seu estado natural deve ser mantido, ou seja, em caso de dúvida sempre deve-se decidir em favor do acusado (NUCCI, 2010, p. 246).

Haveria, então, incongruência entre o sistema positivado e a nova orientação do Supremo Tribunal Federal (STJ - HC 126292, j. 17/02/2016)? Em outras palavras, a determinação para início imediato do cumprimento de pena constante da sentença condenatória, seja em regime fechado, semiaberto ou aberto, a partir da condenação em segunda instância, a despeito de ainda não ter havido o trânsito em julgado, ${ }^{1}$ aplicar-se-ia a todos os casos ou haveria um critério a ser adotado, de forma a distinguir os casos aplicáveis? Eis o problema de pesquisa proposto nesse artigo.

Portanto, segundo o que pensamos, é preciso reafirmar a força normativa do princípio do in dubio pro reoem dados casos, uma vez preenchidos determinado requisitos. É o que pretendemos demonstrar, utilizando o método hipotético-dedutivo, as fontes doutrinárias, legais e jurisprudenciais, com ênfase no estudo dos direitos fundamentais constantes da Constituição brasileira de 1988 e, daí concluir-se pelo exagero da orientação de cumprimento imediato da sentença penal condenatória de segunda instância em alargamento para todas as situações, razão pela qual há que ser analisada sua aplicação em cada caso. O presente artigo finaliza encaminhando alguns balizadores importantes para essa análise, mas não sem antes passar pelo estudohistórico e prático-jurisprudencial da garantia de inocência presumida até final trânsito em julgado da sentença condenatória.

\footnotetext{
${ }^{1}$ Isso ocorrente ao menos na definição clássica de trânsito em julgado de sentença, com referência à possibilidade de o recurso abordar apenas um ou alguns dos capítulos da sentença, o que provocaria o trânsito em julgado dos que não foram alcançados pela impugnação ou, se ocorrente capítulo único, a sua respectia impugnação via recurso, ainda que em sede dos excepcionais, tem o condão de obstar o trânsito em julgado por inteiro.
} 


\section{HISTÓRICO DO PRINCÍPIO “IN DUBIO PRO REO” E PRESUNÇÃO DE INOCÊNCIA}

A civilização das sociedades é diretamente ligada ao processo criminal, de forma que, examinando todas as leis e práticas judiciais ao redor do mundo, chegamos à conclusão de que os lugares onde o processo é inquisitorial, existe a presença de uma civilização imobilizada.

Assim, o direito à presunção de inocência,foi criado a partir da reforma iluminista, como uma forma de evitar que o acusado fosse submetido às técnicas do sistema da tortura, adotado durante o período da Inquisição, com o intuito de obter uma confissão.

Nessa época buscava-se a prática efetiva e a adoção do sistema da livre observação da prova, exaurindo a ideia de que o acusado teria que comprovar a sua inocência diante da sociedade.

Desta forma, essa regra apareceu com a função de contrapesar as inflexibilidades das leis que mantinham o réu na figura de objeto, ou seja, pretendia impedir que durante o processo o acusado fosse submetido a tortura e opressão para obtenção forçada da confissão.

Os regimes soviéticos e nazifascistas adotavam o pensamento de que a questão da culpabilidade do acusado poderia ser solucionada com base nos princípios prevalecentes, isto é, a sociedade contra o réu.

Esses sistemasadotadospelos Estados totalitários, denominado princípio intervencionista, guiou algumas sociedades ao Direito Penal com foco maior na sua efetiva aplicabilidade do que na função de serventia de todos os cidadãos. Todavia, no período do pensamento jurídico-liberal, o princípio da presunção de inocência se difundiu pelo mundo, sendo aplicado até os dias atuais, como princípio constitucional.

A primeira aparição desse princípio veio introduzida na ideia de Direitos dos Homens, na Declaração do Bom Povo da Virgínea, na qual defendia-se o direito a defesa, a um julgamento dentro de um prazo razoável e justo nos processos criminais, por priorizar o direito à liberdade do cidadão. Aqui já se é capaz de observar a inserção da presunção de inocência em desfavor de uma presunção absoluta de culpabilidade (BENTO, 2007, p.37).

Depois disso veio as Declarações dos Direitos do Homem e do Cidadão de 1789 e 1948, que priorizavam principalmente o tratamento do acusado perante o seu julgamento, não permitindo que este fosse tratado diferentemente ou considerado culpado até comprovação do delito perante a lei. Nesse julgamento era determinado que fossem asseguradas todas as formas de defesa cabíveis e,ainda, garantia-se que o acusado não tivesse nenhum direito limitado para que a pena não fosse, de nenhuma forma, antecipadamente aplicada (VARALDA, 2007, p.2021).

Ainda, também versaram sobre o tema o Pacto Internacional de Direitos Civis e Políticos de 1966, que previa a inocência para acusado até que fosse legalmente comprovada a sua culpa; - que serviu como base para a Administração da Justiça da Infância e da Juventude da Organização das Nações Unidas - a Carta dos Direitos Fundamentais da União Europeia de 2000; e a Convenção Americana sobre Direitos Humanos de 1969, que traz não só a presunção da inocência, como também o direito de recorrer e um rol com outras garantias mínimas, fazendo alusão expressa de que toda pessoa acusada de delito tenha direito à sua inocência presumida enquanto não finalize o processo, ou seja, em que se confirme legalmente sua culpa, esgotados os recurso cabíveis.

Então, esses documentos internacionais, a função do princípio in dubio pro reo, ou princípio da inocência, possui como consequência o impedimento de decretação de uma condenação original, com ausência de prova que dirija a afirmação de incumbência do réu pelas infrações penais que lhe foram designadas. 
Conforme foi consagrado, enfim, na Constituição Federal brasileira de 1988, é garantido a execução dos direitos sociais e individuais, como no caso do LVII, do art. $5 .^{\circ}$, que estabelece que em regra, só deverá haver efetivamente a confirmação de culpa posteriormente o trânsito em julgado de sentença condenatória.

Assim, esse princípio constitucional é essencial na fase de julgamento do réu, tendo em vista que de acordo com este, qualquer espécie de incerteza em relação aos fatos será uma operação em favor do réu, o qual apenas sofrerá condenação caso o tribunal não tenha mais dubiedade em relação arealidade dos fatos e provas apresentadas. Desta forma, entende-se que a função da prova de inocência não é meramente do acusado, mas sim do Estado.

Com isso, cabe afirmar que grande parte dos princípios processuais, inclusive o in dubio pro reo,é baseado no debate em relação ao desenvolvimento e evolução dos direitos do acusado que ocorreu durante os últimos tempos. 


\section{O DESENVOLVIMENTO DOS DIREITOS FUNDAMENTAIS BRASILEIROS E A SUA RELAÇÃO COM O PRINCÍPIO DA PRESUNÇÃO DE INOCÊNCIA}

O contemporâneo período democrático determina que os direitos fundamentais sejam devidamente cumpridos, e, em razão disso, o princípio da inocência foi inserido na Constituição Federal Brasileira de 1988.

O maior desafio na atualidade é a inserção das garantias fundamentais estabelecidas nos textos constitucionais para a aplicabilidade na prática, pois muito embora escritas e reiteradas em tratados internacionais, nem sempre são aplicadas ao direito positivo com tanta facilidade.

Sabe-se que os direitos individuas são protegidos pela Constituição, em seu artigo 60, $\S 4 .^{\circ}$, inciso IV, na forma de cláusulas pétreas, o que significa que não poderão ser modificados por Emenda Constitucional - vide Paulo Bonavides (2004, p. 564). Isso demonstra a intenção do legislador em garantir a aplicação desses direitos. ${ }^{2}$

Para aplicar a teoria de forma que seja alcançada a sua efetiva prestabilidade diante da sociedade, com a finalidade de conceder aos cidadãos o efetivo direito à segurança, igualdade, justiça, bem-estar social, liberdade, como disposto no preâmbulo da Constituição Federal do Brasil, o Poder Judiciário utiliza-se da interpretação desses direitos e de outros princípios e garantais previstos nesta.

Quanto aos princípios, para Humberto Ávila (2013, p.136) eles possuem um caráter genérico em sua materialidade, o que significa que não há uma predeterminação da sua aplicabilidade. Essa característica possibilita que existam interpretações diferentes conforme o entendimento de quem os emprega.

No que se discute a consideração de alguns princípios como direitos fundamentais, para esse trabalho destaca-se o princípio da presunção da inocência/não culpabilidade - torna-se relevante discutir como funciona a sua relativização.

Para Deilton Ribeiro Brasil (2016, p. 385) as normas de direito fundamental "são as normas constitucionais que preveem tais direitos, verdadeiras emanações da dignidade da pessoa humana", o que significa que esses direitos derivam de normas com natureza de princípio. Para que os direitos fundamentais possam ser derrotados ou regulados, é preciso que seja em relação a outro direito fundamental ou a algum interesse público previsto na Constituição Federal (SILVA, 2010, p. 246).

Isso significa que há uma relativização na aplicação desses direitos diante de um caso concreto - o que possibilita a interpretação supracitada -mas que não exclui, em nenhum momento, a necessidade da tutela dos direitos fundamentais. O que ocorre é um equilíbrio na sua aplicabilidade ao se considerar a sua adequação, necessidade e proporcionalidade à realidade dos fatos (SOUZA, 2011, p. 26-30).

Ademais, com base nos estudos do histórico do desenvolvimento dos direitos fundamentais, cabe retomar que além de constarem na Constituição nacional, também foram sancionados nos tratados internacionais, através dos quais o Brasil conquistou a consideração e deferência em relação aos direitos humanos.

\footnotetext{
${ }^{2}$ Essa importância é confirmada por Paulo Bonavides (2004) aoclassificar, dentre os direitos de primeira geração, os direitos da liberdade, sendo que historicamente possui características de proteção individual. Ainda, tece considerações sobre os direitos civis e políticos, em espécie, bem como faculdades ou atributos da pessoa, com certa dose de subjetividade, como direitos de resistência ou de oposiçãoao modelo de governo eleito.
} 
Essa aliança internacional implica em uma cobrança da obrigação que determinada nação assume, tendo em vista que esses tratados seguem o princípio denominado pacta sunt servanda.

Neste sentido, de acordo com o jurista Celso D. de Albuquerque Mello, a teoria monista possui dois posicionamentos:resguarda a predominância do direito nacional e a outra do internacional. Todavia, seja qual for a posição aderida, não há de se falar em modificação no direito brasileiro, uma vez que além do princípio da inocência ser adotado pela Constituição nacional (art. 5. ${ }^{\circ}$, LVII), o Estado reiterou a existência do mesmo na Declaração Universal dos Direitos do Homemde 1948, art.11, e na Convenção Americana de Direitos Humanos (Pacto de San José da Costa Rica) de 1969, art.8 , item 2, aprovada pelo Congresso Nacional, através de Decreto Legislativo, sendo que o seu texto foi integrado no ordenamento jurídico brasileiro.

Em seu texto, a Declaração Universal dos Direitos do Homem de 1948 afirmou o direito do acusado à presunção de inocência.

Assim, combinado com a Convenção Americana de Direitos Humanos cujotexto determina que "toda pessoa acusada de delito tem direito a que se presuma sua inocência enquanto não se comprove legalmente sua culpa", atesta-se que o princípio adotado da presunção de inocênciaacarreta algumas garantias para o querelado: que ele deverá ser considerado inocente até ser comprovadamente culpado nos termos da lei; e que cabe a quem acusa a comprovação da culpabilidade do sujeito, não sendo o mesmo obrigado a demonstrar sua inocência, haja vista que a sua culpa deve ser "provada".

Desta forma, em caso de dubiedade no ápice do julgamento, o acusado deverá ser beneficiado. Isso consiste no sistema chamado de in dubio pro reo.

Outra garantia é a proibição de retenção da liberdade anterior ao momento de proferida a sentença condenatória. Como o texto da Constituição Federal, em seu art. 5. ${ }^{\circ}$, inciso LVII, determina que "ninguém será considerado culpado até o trânsito em julgado de sentença penal condenatória", percebe-se que há uma exigência que as vias judiciais se esgotem para que o indivíduo seja definitivamente considerado culpado. Deflagrando, então, a necessidade da aplicação, sem restrições, do princípio da presunção da inocência em seu caráter de extensão da garantia da dignidade da pessoa humana (MEYER-PFLUG; COUTO, 2016, pp. 403-404).

Observa-se, então, que apesar de existir a possibilidade de realizar interpretações para a aplicação na prática dos direitos fundamentais, principalmente considerando que nesse caso a presunção de inocência é um princípio - que por sua natureza genérica não gera um procedimento específico de aplicabilidade - este não pode ser completamente desconsiderado pelos Tribunais Superiores por ser norma de direito fundamental nacional e internacionalmente garantida.

\section{A APLICABILIDADE DO PRINCIPIO NO DIREITO PROCESSUAL PENAL}

Ao falar de processo penal, não podemos defini-lo apenas como um instrumento de aplicabilidade de punição estatal, mas simcomo um meio através do qual se garanta a liberdade legal dos réus. Assim, pode-se afirmar que o processo é efetivamente o uso e aplicação dos direitos e garantias fundamentais estabelecidos na Constituição.

Analisando as teorias existentes em relação ao direito processual contemporâneo e os direitos fundamentais, o princípio in dubio pro reo é classificado como um item essencial do 
direito fundamental do indivíduo a presunção de inocência, ou seja, não podemos considerarque é um princípio geral de direito, tendo em vista que se trata de uma garantia constitucional.

De acordo com alguns juristas, ao mesmo tempo em que o princípio da legalidadefaz oposição a condenação por um fato que não esteja descrito na norma legal, o in dubio pro reodetermina que não poderá existir punição com a inexistência de prova da ocorrência e da culpabilidade. Desta forma, qualquer tipo de ação tomada durante o processo, ou até mesmo nos recursos, não poderá suprimir o princípio do in dubio pro reo.

Cabe destacar aqui a possibilidade de utilização de habeascorpus dentro dos limites de aplicação desse princípio. Ainda, conforme Guilherme de Souza Nucci (2010, p. 245), da mesma forma que em havendo dúvida fundada indica-se o recebimento da peça acusatória, em chegandose ao final do processo, persistindo a dúvida, o réu deve ser absolvido. Igualmente, se a dúvida se instaura no tipo de peça cabível à defesa, como por exemplo, na impetração do habeas corpus, em não sendo um erro grosseiro, o processo deve ser aproveitado, também em prestígio ao princípio da presunção de inocência e do aproveitamento dos atos processuais, com esteio na instrumentalidade das formas.

Há de destacar também a execução provisória das penas, uma vez que esse instituto do direito processual se vincula às determinações da presunção de inocência ao significar uma execução da pena estipulada antes do trânsito em julgado.

Diferentemente da ideia da predominância do in dubio pro reo, Suxberger e Amaral (2017, p. 194-199) entendem que a Constituição Federal não deve ser interpretada literalmente quanto à espera do trânsito em julgado para que a pena produza efeitos. Para eles, a literalidade prejudica o funcionamento do processo penal e impede a aplicação de outros princípios fundamentais, e defendem que deve haver uma interpretação constitucional sistemática, para sua aplicação ampla. Enfim, esses autores argumentam que a responsabilidade penal é apuração exclusiva que se extrai em um processo penal com as garantias inerentes, incluindo a paridade de armas (v.g. contraditório, ampla defesa, vedação de provas ilícitas). ${ }^{3}$

De outro modo,ainda referente aos institutos do processo penal, o jurisconsulto espanhol Bacigalupo (1988, p. 21)defende que os objetivos dos recursos - igualdade das decisões e a justiça - demandam que as normas a serem consideradas para apuração do fato devem ser classificadas como normas substantivas no momento em que for exercida a lei, e, dentro do rol destas normas, está presente o princípio da presunção e inocência.

Aliás, o conceito desse princípio deriva da ideia de dignidade da pessoa humana (NUCCI, 2010, p. 239). ${ }^{4}$

\footnotetext{
${ }^{3}$ Suxberger e Amaral (2017) chegam a afirmar quea condenação não pode ser baseada em um juízo deprobabilidade, pois na dúvida o réu será beneficiado. Então aparece a importância do dever de fundamentação da decisão. Todavia, parecia essa premissa apontar para a vedação da execução da sentença obtida apenas em segundo grau de jurisdição. Não é o caso. Os autores afirmam que o segundo grau de jurisdição é exercido no respectivo tribunal local, salvo processos originários; razão pela qual estariam preenchidas as condições para uma execução. A logicidade estaria justamente na confirmação de uma condenação de primeiro grau em segunda instância. Mas, como se verá, não nos parece que essa leitura seja a melhor para todos os casos, sobretudo em sistema jurisprudencial que se firmou na melhor interpretação ao acusado.

${ }^{4}$ Quando se tenham duas leituras possíveis, não se poderá optar pela mais gravosa ao acusado. Nucci (2010)leciona quea posse do estado de inocência(um elo para liberdade) é indisponível e irrenunciável, faz parte da própria natureza humana,em respeito ao princípio constitucional da dignidade da pessoa humana. Eis por que se presume a inocência, notadamente o indiciado ou réu não pode ser considerado, prima facie, culpado.
} 
Nesta perspectiva, Juan Alberto Belloch (1985, pp. 15-52) defende que a concepção de que a criação do direito a presunção de inocência, considerado direito e garantia fundamental, na área do direito processual penal, tornou-se um princípio essencial no emprego das funções desenvolvidas pelo Tribunal Superior e os demais.

De acordo com as ideias desse juristaespanhol, a presunção de inocência afeta não apenas as provas relativas a atuação do delito, mas também a imposição de provas referentes ao tipo penal, cabendo dizer que cada elemento do fato é considerado uma ocasião de agravante do delito.

Contudo, a estrutura do processo penal depende não apenas da natureza do Direito Penal e sua evolução, como também da organização da jurisdição penal. Se a organização judiciária, o Direito Penal e o Processo Penal não forem devidamente coordenados a justiça penal será ineficaz (FERREIRA, 1986, p.26)

Diante de todo o exposto,fica evidenteque os órgãos da jurisdição criminal do Poder Judiciário são todo incorporados pelo direito à presunção de inocência, eo Poder legislativo, da mesma forma, sem detrimento de qualquer dos tribunais, deve conceder a inocência ao indiciado seja qual for o processo.

Portanto, é importante que a sociedade no geral, os legisladores e os juízes de todas as instâncias deem a devida importância a esse princípio, afim de que haja uma mudança significativa na aplicabilidade dos direitos humanos e garantias constitucionais, de forma geral. E que apesar de existirem algumas defesas no sentido de que deve haver a execução da pena antes do trânsito em julgado, essa relativização deve ser discutida mais profundamente.

\section{O SEGUNDO GRAU DE JURISDIÇÃO E A APLICAÇÃO DO PRINCÍPIO}

Caso o processo já tenha sido encaminhado à segunda instância, será aplicada a regra do art. 615 do Código de Processo Penal, o qual estabelece que o tribunal deverá dirimir com base na maioria dos votos.

Ao observar o artigo 615 do Código de Processo Penal, cabe dizer que a lei não determinou o número exato de magistrados que integram a câmara do tribunal. Vale dizer, a lei não fixou como se dá a formação da maioria dos votos, sendo que tal critério somente se ajusta com a letra do Regimento Interno do respectivo tribunal e, à rigor prático, quando instalada a sessão de julgamento. Assim, os tribunais criam regras procedimentais nos regimentos internos, os quais estabelecem o número ímpar, normalmente três julgadores, membros nos julgamentos das câmaras, podendo haver infringência no julgado que revele a ampliação do número de julgadores em etapa seguinte ou ser encaminhado o julgamento diretamente para o pleno do tribunal, em dadas matérias.

No plano prático, cada vez mais a presunção de inocência, amparada pela Constituição Federal como forma de garantia individual, bem como dos dispositivos infraconstitucionais (Código de Processo Penal, em seus artigos 615 e 386, inciso VI) está se tornando objeto central nas decisões judiciais, uma vez que esse princípio intervém na problemática da liberdade provisória.

Desta forma está se transformando cada vez mais em algo relevante no atual quadro do ordenamento jurídico penal brasileiro. 
Com isso, cabe mencionar alguns julgados de ambas as Turmas do Supremo Tribunal Federal, ratificandoo exercício do uso do reconhecimento constitucional da condição de inocência do acusado previsto no art. $5^{\circ}$, LVII, da Constituição Federal, como no caso em que houve determinação de reinclusão de candidatado em concurso público, excluído do certame por existência de processo penal em curso, ${ }^{5}$ afinal, tem-se por ferido o princípio a eliminação de candidato do certame se a acusação está na fase de inquérito ou ação penal sem pena condenatória com trânsito em julgado. ${ }^{6}$

Tal posição tomada pelo Supremo Tribunal Federal é baseada no argumento de que a presunção de inocênciaexiste para impor certas limitações ao poder do Estado,e é destinada aos cidadãos da sociedade, para que os mesmos tenham seus direitos fundamentais garantidos de forma incontestável, pelo fato de possuir característica de natureza constitucional. Isso representa uma conquista histórica da luta ininterrupta contra a o despotismo do poder do Estado.

Cabe expor a observação de que, em determinado momento, o texto da Constituição Federalexaure a presunção de inocência, no momento em que ocorre o trânsito em julgado da condenação na esfera penal. Antes disso, o Estado não poderá referir-se ao acusado como se o mesmo já estivesse na qualidade efetiva de culpado pelo ato.É desta forma que o princípio da presunção de inocência é aplicado ao Poder Público, ou seja, nenhum dos seus agentes ou autoridades poderão violar o tratamento de forma imparcial aos indiciados ou réus. Tal entendimento é evidenciado frequentemente pelo Supremo Tribunal Federal, como o fez no julgamento do Habeas Corpus n. 95.886/RJ, de relatoria do Ministro Celso de Mello, reconhecendo que o fato de ter sido imputado ao acusado a prática de um crime grave e, ainda que ele seja um criminoso reiterado, há insuperável vedação constitucional, com base no art. $5^{\circ}$, LVII, em querer presumir-lhe a culpabilidade. Somente a sentença penal condenatória irrecorrível dará ao Estado-Juiz a executoriedade da decisão. Em outras palavras, não se admite a execução provisória de uma decisão penal condenatória.

No entanto, em 2016, o Pleno do Supremo Tribunal Federal decidiu, por maioria de sete votos, pelaexecutoriedade provisória de acórdão penal condenatório proferido em grau de apelação. $\mathrm{O}$ fato da sujeição ao recurso especial e/ou extraordinário, segundo esse entendimento, não comprometeria o princípio constitucional da presunção de inocência afirmado pelo artigo $5^{\circ}$, inciso LVII da Constituição Federal.

O votocondutor do julgado, exarado pelo Ministro Relator Teori Zavascki, fixou que o exame dos fatos fica exaurido em segunda instância, no julgamento da apelação, onde é fixado a responsabilidade penal do acusando; ou também se esgota por via da revisão criminal, através da qual o tribunal poderia rever a classificação do crime, absolver, anular ou reduzir a pena.Outros Ministros compartilharam dessa mesma opinião como Gilmar Mendes, Edson Fachin e Luiz Roberto Barroso, e ainda argumentaram no sentido de que: a credibilidade da justiça ficaria abalada caso um condenado por crime grave não cumpre sua pena em tempo razoável; e que o Tribunal do Júri perde a soberania de suas decisões com a suspensão dos efeitos das condenações até o julgamento de todos os recursos protelatórios interpostos pela defesa em vias extraordinárias, o que incentiva a interposição sucessiva desses recursos.

Em contraposição, o Ministro Celso de Mello afastou o efeito vinculante da decisão desse HC 126.292/SP, no julgamento da Medida Cautelar no HC 135.100/MG ao enfatizar que modelo político-jurídico do Estado Democrático de Direito é o que justifica a existência da presunção de inocência, porquanto as imputações criminais jamais se presumem provadas, até que sobrevenha

\footnotetext{
${ }^{5}$ STF - RE no 450.971/DF-AgR, Primeira Turma, Relator o Ministro Ricardo Lewandowski, DJe de 21/2/11.

${ }^{6} \mathrm{STF}$ - AI no 769.433/CE-AgR, Segunda Turma, Relator o Ministro Eros Grau, DJe de 12/2/10.
}

Revista de Direito Brasileira | São Paulo, SP | v. 19 | n. 8 | p. 366 - 381 |Jan./Abr. 2018 
o trânsito em julgado. A gravidade ou hediondez do delito não vinga para se afastar o direito fundamental de qualquer pessoa de ser presumivelmente inocente.

Fica claro nesse voto que o Ministro enaltece a aplicação do princípio da presunção da inocência como garantia constitucional e direito fundamental indisponível, não podendo ser relativizado em detrimento da liberdade do acusado, que não pode ser ofendida por interpretações e jurisprudência que pregam a ideologia da lei e da ordem em detrimento de direitos e garantias fundamentais previstos na Constituição Federal.

No Superior Tribunal de Justiça, também há entendimentos referente a prevalência da presunção de inocência, como na decisão monocrática do MinistroAntônio Saldanha Palheiro no HC 400404, acrescentando que se ainda restam recursos na instância ordinária, com mais razão deve-se reconhecer a ilegalidade da execução da pena, que ainda não restou confirmada em segundo grau. É o caso quando se processam os embargos de declaração ou agravo.

Está evidente a posição de alguns Ministros do Superior Tribunal de Justiça de que a orientação do STF - quanto a execução de sentença penal condenatória confirmada por Tribunal de segundo grau não comprometer o princípio constitucional da presunção de inocência - não vincula todas as decisões referentes a essa matéria, devendo ser analisado o caso concreto, impedindo, assim, que o acusado tenha seus direitos fundamentais limitados prematuramente.

Disso resulta, sob uma análise hermenêutica do ordenamento jurídico brasileiro, o entendimento de que é direito básico da pessoa humana receber tratamento digno, sendo vedada a exposição vexatória ou o constrangimento ilegal, ou qualquer situação de mesma natureza, que afetem ou resultem em imposição prematura de culpa ao acusado, antes de proferidotrânsito em julgado decisivo da sentença condenatória.

Esse argumento possui fundamento na Constituição Federal do Brasil, artigo $5^{\circ}$, LVII, o qual define essa regra de tratamento - repita-se: "Ninguém será considerado culpado até o trânsito em julgado de sentença penal condenatória".

Desta forma, de acordo com o exposto, é importante esclarecer que a presunção de inocência não perde a força e aplicabilidade no decorrer do processo, ainda que confirmada a condenação penal em segunda instância ou qualquer outro órgão de inferior jurisdição, deve permanecer em favor do acusado seu direito fundamental, que só deixará de existir com o trânsito em julgado da sentença penal condenatória.

\section{ESTABELECIMENTO DE DIFERENCIAÇÃO DE CASOS: CRITÉRIO RECORRIBILIDADE-ABRANDAMENTO}

Aspectos procedimentais a parte, a guisa do que foi comentado sobre o artigo 615 do Código de Processo Penal, o que diferencia um caso de outro é a conformação legal (chamada tipicidade) e ainda, um segundo aspecto, a culpabilidade (materialidade e autoria).

E essa conformação legal (ou sua negativa) dá o tom e limites entre tipicidade e atipicidade do fato histórico, bem como produz diferenças na pena a ser aplicada ao fato típico, se culposo ou doloso, mediante dolo eventual, cabendo fixar tais limites no campo interpretativo, com esteio também na mais atual doutrina, que faz referência ao direito penal comparado, como, por exemplo, utilizando, por exemplo, a recklessness e a miseendanger (SALES, 2017, p. 125). Tecer comentários à prova no processo, como alude a doutrina italiana, trata-se da revelação de um standard racional de qualificação e mensuração do risco dentro da sociabilidade. (RAMACCI, 2013. p. 344)

A seu turno, a prova da materialidade delitiva, muito embora seja fruto de um caminho lógico a ser trilhado (ALENCAR, 2017, p. 205), permeia a gradatividade sugerida pela prova indiciária (art. 239 do Código de Processo Penal), pela prova indireta ou até se chegar a uma 
maior certeza do fato pela prova direta evalidamente colhida no processo (MANZANO, 2012, p. 847).

Nessa esteira, para se dizer o mínimo, com base no Código de Processo Penal, em seus artigos 615 e 386, inciso VI, o magistrado não poderá condenar o réu perante uma dubiedade em relação à tipicidade do fato criminoso imputado ao acusado (v.g. dúvida quanto ao dispositivo aplicado, com penas de naturezas diversas), quanto mais determinar sua prisão antes do trânsito em julgado. É o caso quando se instaura a dúvida sobre a tipicidade fática, isto é, se aplicável uma norma mais gravosa ou outra menos gravosa, que implique alteração de regime. Então devese optar pela pena menos gravosa ao acusado, beneficiando-o, no caso de alteração de regime, ainda que decorrente de impugnação em recursos excepcionais. Defensável igual solução em caso de dúvida em relação a sua culpabilidade (v.g. de novo a dúvida não se instala no plano fático, mas se dos fatos consolidados decorre a culpabilidade do acusado), nessas situações o réu deverá sempre ser beneficiado pela leitura mais branda, enquanto aguarda o julgamento definitivo.

Em caso de debate sobre dúvida fundada dentre qualquer desses dois requisitos para se chegar à pena, uma que leva de um regime fechado ao semiaberto, ou do regime semiaberto ao aberto, ou do fechado diretamente ao aberto, em todas essas situações, até que não haja o trânsito em julgado, o cumprimento da pena deve ser obstado, aguardando o trânsito em julgado da decisão, sob pena de ocorrer, no caso de revisão do julgado, a injustiça da decisão. Trata-se de aplicação do que batizamos de critério recorribilidade-abrandamento.

Um único caso de injustiça já justificaria toda a cautela no procedimento. Ou seja, a presunção de inocência deve prevalecer e aguardar o resultado dos recursos excepcionais. Afinal, uma casa de Justiça não pode deixar alguém ser preso ou cumprir regime semiaberto, quando recorre para se livrar solto e, em tendo êxito recursal, nunca deveria ter sido preso ou levado à colônia agrícola penal.

Uma leitura também possível dessa regra seria o início do cumprimento de pena no regime mais brando, aquele pleiteado justificadamente pelo acusado. Então deve ser aplicado o in dubio pro reo.

De outra forma, se alguém recorre para diminuir a pena, mas intenta o enquadramento no mesmo regime, então a jurisprudência firmada para cumprimento imediato de pena, em regime fechado ou semiaberto, a partir da condenação em segunda instância (STJ - HC 126292, j. 17/02/2016), é válida e eficaz. Condiz, em última análise, com a vedação ao retrocesso e o combate à impunidade, valores tão caros e de alto apreço pela sociedade brasileira.

Nem se diga que, se não há recurso, a decisão em segunda instância já se tornou definitiva. Também não se aplica esse pensamento se o recurso é apenas do órgão acusador, que procura majorar a pena.

Em resumo, a velha garantia de presunção de inocência incondicional, até o trânsito em julgado, não mais se justifica. Também não se pode levar a cabo toda condenação em segunda instância, como se fosse o veredito final, para automaticamente se dar o cumprimento da pena. Há que se levar em conta o que se impugnou no recurso excepcional (nos exatos termos dos limites da devolutividade recursal) e a sua relevância na argumentação (plausibilidade de minimamente ser apreciado o pleito de reforma ou anulação da decisão). Então restarão presentes os requisitos do in dubio pro reo, não se justificando a prisão imediata em segunda instância, devendo-se aguardar o julgamento definitivo nas instâncias superiores. Não fosse assim, estaria toda errada a doutrina e jurisprudência criada desde o advento do Código Penal (Decreto-Lei $\mathrm{n}^{\circ}$ 
2.848, de 7 de dezembro de 1940) e do Código de Processo Penal (Decreto-Lei no 3.689, de 3 de outubro de 1941).

\section{CONCLUSÃO}

Diante do conteúdo exposto, podemos afirmar que a garantia fundamental de presunção de inocência é um direito fundamental de todos os cidadãos, sem qualquer distinção, garantido pelo direito nacional e internacional, e deriva do direito fundamental da liberdade e da dignidade da pessoa humana.

O emprego do termo presunção de inocência advém da Convenção Americana sobre Direitos Humanos de 1969, mas é conhecido também como in dubio pro reo ou princípio da nãoculpabilidade.

Partindo do conceito do princípio da presunção de inocência ('todo acusado deverá ser considerado inocente até que seja provada sua efetiva culpabilidade') existem duas regras a serem seguidas: regra de tratamento e regra probatória.

Na primeira, o acusado não poderá ser encarado na qualidade de autor da infração penal antes de transitada em julgado a sentença penal condenatória, devendo ser tratado de forma digna no decorrer do processo, sem sofrer exposição vexatória ou constrangimento ilegal. Já a regra probatória obriga a acusação comprovar a culpabilidade do sujeito.

Destarte, por força dessa regra, o indiciado possui o direito de respeito e consideração, sendo vedado qualquerprematuridade de juízo condenatório ou verificação de possíveis e hipotéticas existências de culpabilidade do mesmo, seja por incidentes na prática, quanto por palavras, gesticulações, ou qualquer outra natureza de acusação com impropriedade que mantenha o acusado em situação de afronta ou vexação.

Em relação a aplicabilidade e pertinência da presunção de inocência, não estão apenas restringidas nos âmbitos do direito processual penal e do direito penal. É valido assimilar que, embora essa garantia fundamental esteja historicamente relacionada ao processo penal, também possui repercussões fora das esferas criminais, em prol da sociedade, em oposição ao abuso de poder, opressão ou despotismo do Estado, evitando, assim,que outras espécies de sérios efeitos na esfera jurídica intentem contra o cidadão - com exceção dos casos estabelecidos na Constituição, espécies essas de juízos morais baseados em ocorrências jurídicas ainda não determinadas, e portanto, instáveis.

O princípio da presunção de inocência não pode ser extirpado do sistema legal, mormente porque existe percentual significativo de reformas de sentenças condenatórias nos tribunais superiores brasileiros. Ainda que fosse uma única possibilidade de reforma, com a retirada da pena privativa de liberdade, já seria justificável a manutenção do princípio de presunção de inocência e o aguardo do réu em liberdade, expirando o veredito final.

Por fim, colhe-se um dado importante para que a pena não seja levada a cabo na segunda instância: os prazos prescricionais não correm durante o processamento recursal e os delitos são praticados, em mais de $90 \%$ dos casos, por pessoa com menos de 30 anos de idade. Nesse sentido, é possível visualizar que o cumprimento de pena em segunda instância é decisão, para se dizer o mínimo, precipitada e que causará prejuízo irreparável para aquele que, em sendo compelido a cumprir a decisão condenatória de segunda instância, vg. já preso, posteriormente sobrevenha a reforma da decisão admitindo a absolvição. 
Para citar um exemplo, podemos trazer à colação o julgamento do crime famélico e ainda, o julgamento de crimes falimentares, que, não havendo uma alta periculosidade, admite-se a absolvição, ainda que o crime esteja constituído e capitulado como tal.

Não estamos aqui a defender a impunidade, apenas dizer que nossas cadeias estão abarrotadas de autores de pequenos furtos, dentre outros, quando grandes estruturas criminosas continuam a operar na impunidade. Deve-se separar o joio do trigo.

Com isso, e baseado em julgamentos recentes dos Tribunais superiores podemos concluir que, apesar da posição do Supremo Tribunal Federal entender que a execução provisória da pena não interfere no princípio da presunção de inocência, uma vez que a análise da matéria de fato se esgotaria nas instâncias inferiores, ainda há defensores da prevalência desse princípio no Supremo e como no Superior Tribunal de Justiça que entendem que em caso de dúvida devese decidir em favor do acusado sempre. Todavia, nem uma e nem outra, se adotada posição pura, são soluções excludentes. O sistema processual penal brasileiro deve conviver com as duas soluções, a depender do caso concreto e, em especial, a probabilidade

\section{REFERÊNCIASBIBLIOGRÁFICAS}

ALBUQUERQUE MELlo, Celso D. de. Curso de Direito Internacional Público, vol. 1, RJ, Editora Renovar, 1992.

ALENCAR, RosmarAntonni Rodrigues Cavalcanti de. Requisitos da prova pericial em matéria criminal.In: Revista Brasileira de Ciências Criminais. São Paulo: Revista dos Tribunais, vol. 136/2017, pp. 205 - 234, Out./2017.

ÁVILA, Humberto. Teoria dos princípios: da definição à aplicação dos princípios jurídicos. 14 ed. São Paulo: Malheiros, 2013.

BACIGALUPO, Enrique. Presunción de inocencia, "in dubio pro reo" y recurso de cassación, Madrid, 1988.

BARROSO, Luís Roberto. Curso de Direito Constitucional Contemporâneo: os conceitos fundamentais e a construção do novo modelo. 2. ed. São Paulo: Saraiva, 2010.

BELLOCH, Juan Alberto. Algunasprecisionesen torno a lapresunción de inocencia, in "Los Derechos Humanos ante la Criminologia y el Derecho Penal", pp. 15 a 52, Servicio Editorial, Universidaddel Pais Vasco. Disponível em:http://www.ehu.eus/es/web/ivac/los-derechoshumanos-ante-la-criminologia-y-el-derecho-penal>. Acesso em 26 de maio de 2017.

BENTO, Ricardo Alves. Presunção de inocência no processo penal. São Paulo: QuartierLatin, 2007.

BRASIL. Comissão de Direitos Humanos e Minorias - CDHM. Regras mínimas para a Administração da Justiça da Infância e da Juventude - Regras de Beijing (1985). Disponível em: http://www2.camara.leg.br/atividade-legislativa/comissoes/comissoes-permanentes/cdhm/comitebrasileiro-de-direitos-humanos-e-politica-externa/RegrMinNacUniAdmJustInfJuv.html . Comissão de Direitos Humanos e Minorias - CDHM. Regras mínimas para a proteção dos jovens privados de liberdade (1990). Disponível em: /www2.camara.leg.br/atividadeRevista de Direito Brasileira | São Paulo, SP | v. 19 | n. 8 | p. 366 - 381 |Jan./Abr. 2018 
legislativa/comissoes/comissoes-permanentes/cdhm/comite-brasileiro-de-direitos-humanos-epolitica-externa/RegNacUniProtMenPrivLib.html>. Acesso em 19 mai. 2017.

BRASIL, Deilton Ribeiro. A garantia do Princípio Constitucional da Presunção de Inocência (ou de não-culpabilidade): um diálogo com os direitos e garantias fundamentais. Revista de Direitos Brasileira, São Paulo, v. 15, n. 6, pp.376-398, set./dez. 2016. Disponível em: http://www.rdb.org.br/ojs/index.php/rdb/issue/view/v.15\%20n.6\%20\%282016\%29>. Acesso em: 16 mai. 2017.

BONAVIDES, Paulo. Curso de Direito Constitucional. 14 ed. São Paulo: Malheiros, 2004.

BONFIM, Edilson Mougenot. Curso de Processo Penal. 6. ed. São Paulo: Saraiva, 2011.

CANOTILHO, José Joaquim Gomes. Direito Constitucional, Livraria Almedina, Coimbra, 1992.

CICCO, Cláudio de; GONZAGA, Álvaro de Azevedo. Teoria geral do Estado e ciência política. 7. ed. São Paulo. Revista dos Tribunais, 2016.

EUR.LEX. Carta dos Direitos Fundamentais da União Europeia (2000/C 364/01). Disponível em: . Acesso em 20 mar. 2016.

FERREIRA, Manuel Cavaleiro de. Curso de Processo Penal, vol. 1, Editora Danúbio, Lisboa, 1986.

GOMES, Luiz Flávio. A lei das Medidas cautelares é um avanço?Consultor Jurídico, 23 jun. 2011. Disponível em: <http://www.conjur.com.br/2011-jun-23/coluna-lfg-lei-medidas-cautelaresalternativas-avanco>. Acesso em: 13 fev. 2017

MANZANO, Luís Fernando de Moraes. Conceito de indícios de autoria e prova da materialidade delitiva para a decisão de pronúncia. In: Doutrinas Essenciais Processo Penal. São Paulo: Revista dos Tribunais, vol. 3, p. 847 - 883, Jun./2012.

MEYER, Emilio Peluso Neder. Presunção de inocência até a condenação em segunda instância? 2016. Disponível em: <https://jota.info/artigos/presuncao-de-inocencia-ate-a-condenacao-emsegunda-instancia-19022016>. Acesso em: 17 fev. 2017

MEYER-PFLUG, Samantha Ribeiro; COUTO, Mônica Bonetti. A Presunção de Inocência, a Constituição e o STF: Comentários ao HC 126.292/SP. Revista de Direito Brasileira. São Paulo. V. 15, n. 16, pp. 399-405, set./dez. 2016. Disponível em: http://www.rdb.org.br/ojs/index.php/rdb/issue/view/v.15\%20n.6\%20\%282016\%29>. Acesso em: 16 mai. 2017.

NUCCI, Guilherme de Souza. Princípios penais e processuais penais. São Paulo: Editora Revista dos Tribunais, 2010.

RAMACCI, Fabrizio. Corso didirittopenale: parte generale. 5. ed. Torino: Giappichelli, 2013. 
SALES, Sheila Jorge Selim de. Anotações sobre o estudo da recklessness na doutrina penal italiana: por uma terceira forma de imputação subjetiva? In: Revista Brasileira de Ciências Criminais. São Paulo: Revista dos Tribunais, vol. 137/2017, pp. 125 - 149, Nov./2017.

SCHUMPETER, Joseph A. Capitalismo, socialismo e democracia. Rio: Zahar. 1984.

SILVA, Virgílio Afonso. Direitos fundamentais: conteúdo essencial, restrições e eficácia. 2. ed. São Paulo: Editora Malheiros, 2010.

SOUZA, Rodrigo Telles. A distinção entre regras e princípios e a derrotabilidade das normas de direitos fundamentais. In: Boletim Científico ESMPU. Brasília-DF, ano 10, nº 34, jan.-jun., 2011.

SUXBERGER, Antônio Henrique; GOMES DE AMARAL, Marianne. A execução provisória da pena e sua compatibilidade com a Presunção de Inocência como decorrência do sistema acusatório. Revista de Direito Brasileira, São Paulo, v.16, n.7, pp. 186-210, jan./abr. 2017.Disponível

em:http://www.rdb.org.br/ojs/index.php/rdb/issue/view/v.16\%20n.7\%20\%282017\%29>. Acesso em: 16 mai. 2017.

VARALDA, Renato Barão. Restrição ao princípio da presunção de inocência: prisão preventiva e ordem pública. Porto Alegre: Sergio Antônio Fabris Editor, 2007. 